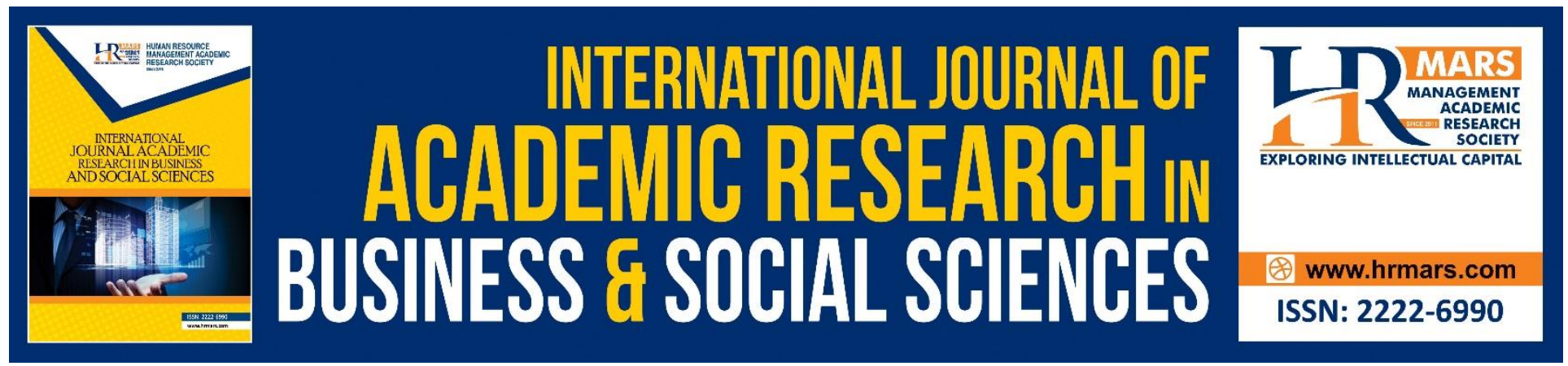

\title{
Drug Risk Behaviour among Malaysian Adolescents
}

\author{
Nor Hafifah Abdullah, Md Azman Shahadan, Mohammad Nasir Bistamam
}

To Link this Article: http://dx.doi.org/10.6007/IJARBSS/v8-i12/5317

DOI: $10.6007 /$ IJARBSS/v8-i12/5317

Received: 19 Nov 2018, Revised: 29 Dec 2018, Accepted: 06 Jan 2019

Published Online: 08 Jan 2019

In-Text Citation: (Abdullah, Shahadan, \& Bistamam, 2018)

To Cite this Article: Abdullah, N. H., Shahadan, M. A., \& Bistamam, M. N. (2018). Drug Risk Behaviour among Malaysian Adolescents. International Journal of Academic Research in Business and Social Sciences, 8(12), 1708-1722.

Copyright: (C) 2018 The Author(s)

Published by Human Resource Management Academic Research Society (www.hrmars.com)

This article is published under the Creative Commons Attribution (CC BY 4.0) license. Anyone may reproduce, distribute, translate and create derivative works of this article (for both commercial and non-commercial purposes), subject to full attribution to the original publication and authors. The full terms of this license may be seen

at: $\underline{\text { http://creativecommons.org/licences/by/4.0/legalcode }}$

Vol. 8, No. 12, 2018, Pg. 1708 - 1722

http://hrmars.com/index.php/pages/detail/IJARBSS

JOURNAL HOMEPAGE

Full Terms \& Conditions of access and use can be found at http://hrmars.com/index.php/pages/detail/publication-ethics 


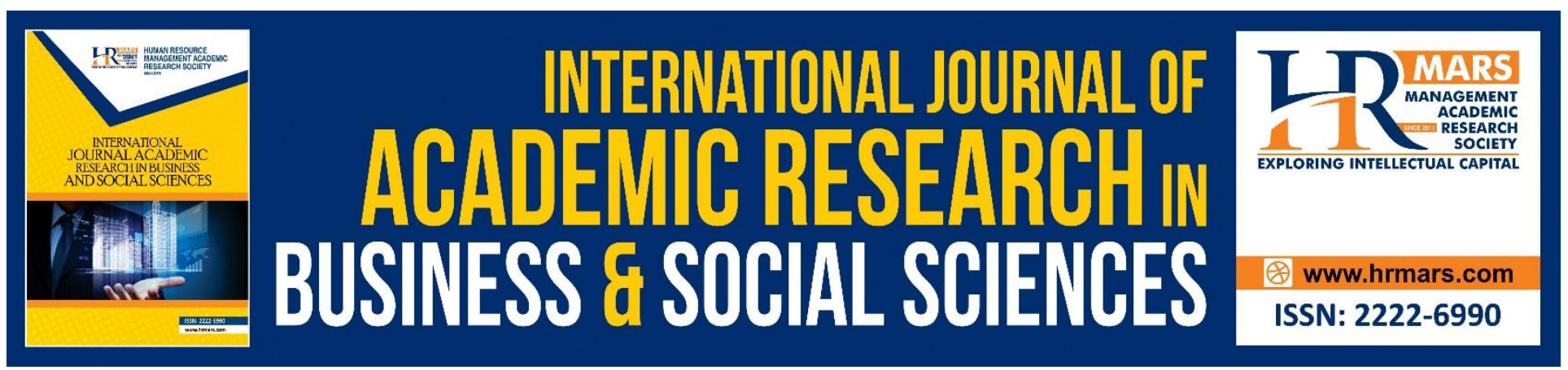

\title{
Drug Risk Behaviour among Malaysian Adolescents
}

\section{Nor Hafifah Abdullah, Md Azman Shahadan, Mohammad Nasir Bistamam}

Psychology and Counselling Department, Faculty of Human Development, Universiti Pendidikan Sultan Idris, 35900, Tanjung Malim, Perak

\begin{abstract}
Malaysia has been overwhelmed with the issues involving adolescent and drug abuse activity nowadays. The purpose of this paper is to conduct Pearson correlation analysis to see the relationship between seven variables in this data set. This current study involves 2894 data from some secondary school students in Malaysia (1357 male, 1537 female) from Kelantan, Pulau Pinang, Kedah, Selangor, Kuala Lumpur, Johor, Sabah and Sarawak with range of age 13 to 14 years old. Analysis shows that there is significant positive linear relationship between drug risk behavior and depression and negative linear relationship between drug risk behavior and social support from family, peer and school, family income and resilience. Further studies are needed to replicate this study by using more advance statistical analysis and at the same time further longitudinal studies assessing the interaction between these construct or variables are crucial at different culture background and adolescence development stage because this study only focus on early adolescence stage.
\end{abstract}

KEYWORDS: Adolescent, Social Support, Family Income, Resilience, Depression, Drug Risk Behaviour

\section{INTRODUCTION}

Adolescence is a milestone in human growth and development as a turbulent period of transition from childhood to adulthood characterized by coexistent changes where it is a critical period of life in which a great deal of biological, psychological, and social changes occurs (Kurt \& Ergene, 2017). According to the World Health Organization, adolescence comprises a period of development between the ages of 10 and 19 years (The World Health Organization (WHO), 2017). The population of adolescents in Malaysia is about 5.4 million, in other words, adolescents make up 19.2 percent of the population of Malaysia (World Health Organization, 2009).

Adolescence stage is a developmental stage that acquire maximize survival and reproductive fitness where risk-taking and subsequent drug experimentation during this developmental period lead to increase likelihood of developing a lifelong addiction, internalizing and externalizing behavior (Jordan \& Andersen, 2017). As this phase is where an adolescent's learning capacity to absorb knowledge, develop habits, and foster skills grow rapidly, this phase become the most vulnerable 
INTERNATIONAL JOURNAL OF ACADEMIC RESEARCH IN BUSINESS AND SOCIAL SCIENCES

Vol. 8, No. 12, Dec, 2018, E-ISSN: 2222-6990 @ 2018 HRMARS

phase in developmental stage for them to drug abuse and therefore, supportive and positive environments are critical to their success (Turnbridge, 5 June 2018).

Aim of this current study is to conduct Pearson correlation analysis to see the relationship or association between variable in this data set that was obtain from the previous research conducted by Mohammad Nasir et al. (2013) which their aim of study is to acquire a descriptive information about the adolescent that involve in drug risk behaviour. After that, the adolescent who have the high risk of drug risk behaviour been chosen to involve in their experimental study. In their study, they didn't conduct this analysis as this part is not the main focus in their research. So, this current study will fill the gap by conducting this Pearson correlation analysis.

In this study, a Pearson correlation analysis which involved the data from 2894 students with age 13 and 14 years old from secondary school at Johor, Kelantan, Pulau Pinang, Kedah, Sabah and Sarawak will be carried out. They are the standard 1 and standard 2 students and they been selected to participated in this study by their class teacher or the school's counsellor based on criteria that have been fixed by the researcher of the previous study.

\section{REVIEW ON DRUG RISK BEHAVIOR AMONG ADOLESCENTS}

Lawrence-Lo (2009) found that during transitional phase from adolescence to adulthood, prevalence of drug use become more serious. One of the negativities frequently encountered in adolescent is the increase in risk behaviours (Kurt \& Ergene, 2017). Risk behaviours such as anti-social behaviours, drug use, suicide, are seen in adolescence as compared to the other developmental stages (Pandian \& Lakshmana, 2017; Skogen et al., 2014; Torikka, 2017).

Research also shows that children who begin using substances in adolescence are much more likely to become addicted than those who begin using after their teenage years (Palamar, GriffinThomas \& Ompad, 2015). Phenomena related to drug risk behavior among adolescent have been studied by many researchers from time to time (Boyas, Kim, Moon, Ruiz, \& Gaines, 2017; Cox, Criss, Harrist, \& Zapata-Roblyer, 2017; Gattamorta, Varela, McCabe, Mena, \& Santisteban, 2017; Kurt \& Ergene, 2017; Marotta \& Voisin, 2017; Rovis, Bezinovic, \& Basic, 2015; Skogen et al., 2014).

Nowadays, Malaysia has been overwhelmed with the issues involving adolescent and drug abuse activity (Baharudin, Krauss, Yacoob, \& Pei, 2017; Mohd Razali, 2015; Sharif \& Mohammad Roslan, 2011). Development problems among adolescent involve negative external environment (low social support from family, peer and school and low family income) (Boyas et al., 2017; Clapp, Isom, \& Thomas, 2016; Foster et al., 2017; Gattamorta et al., 2016; Moore \& McArthur, 2014; Omboto, Ondiek, Odera, \& Ayugi, 2013; Santiago et al., 2017; Wang, 2014) and negative internal environment factor (resilient and depression) (Anderson et al., 2015; Mohd Nasir \& Jusoh, 2013; Racal, 2017; Taylor \& Distelberg, 2016; Torikka, 2017) have a stronger relationship with drug risk behavior. Insufficient social support from family, peers and school, low family income, low resilient level and depression were factors that leads to the adolescent getting involved in drug risk (Gattamorta et al., 2016; Hodder et al., 2017; Khalid \& Kausar, 2016; Kurt \& Ergene, 2017; Newsome \& Sullivan, 2014).

According to the finding from a study conducted by Nachiappan (2015), through the interview with the clients from Association of Malaysian Addicts (PENGASIH), he found that the main factor leading to drug abuse is peer pressure, follow by environmental, curiosity and family factor. His finding is parallel with the statistics issued by Agensi Anti Dadah Kebangsaan (2017), the main factor 
INTERNATIONAL JOURNAL OF ACADEMIC RESEARCH IN BUSINESS AND SOCIAL SCIENCES

Vol. 8, No. 12, Dec, 2018, E-ISSN: 2222-6990 @ 2018 HRMARS

that lead adolescents to involve in drug abuse activity is because of peer pressure where 66,338 cases reported since 2012 until 2017 and the second factor is curiosity with 20,357 cases within the same period.

Through Problem Behavioral Theory (PBT) by Jessor and Jessor (1977), this theory explained a comprehensive conceptual framework to identifying risk and protective factor for adolescent drug use. According to PBT, adolescence is a period of rapid and pervasive change and problem behaviours manifest as adolescents begin to define their identities (Alexander, Obong'o, Chavan, Vander Weg, \& Ward, 2017). The severity of problem behaviours basically depends on configuration of risk and protective factor that exist across three multiple systems in this psychosocial influence theory which are the personality system, the perceived environment system and behaviour system (Alexander et al., 2017).

The personality system includes factors within adolescent that can contribute to problem bahavior (example: low self-esteem, low resilient, low religiosity and depression), the perceived environment system includes environmental factor that influence adolescent's problem behavior (example: low support from parent, peer and school and family income, and lack of positive parental influence) and lastly, the behavior system includes behavior that contribute to problem behaviour (example: risky sexual activity, risky driving and substance use) (White, 2018).

Based on this theory, if there is existence of appropriate models or environment around the adolescents, parental, peer, and school control of risk behavior, social support from family, peer and school can help to protect adolescents from involving in risky behavior and also reduce the effect of risk factor. PBT focused primarily on high-risk or disadvantage population such as low level of socioeconomic status (SES), financially unstable and unsafe communities as this theory assume that this population have low level of resilient from problem behavior because of their environment and life circumstance making the vulnerable to risky behavior such as substance use (Alexander et al., 2017). But differ from current study, as this study included all population either the adolescent came from both, high and low risk population.

Through Problem Behavioral Theory (PBT) that been explained, its shows that adolescents who involved in drug risk behaviour activity came from negative or risky environment. Example of negative and risky environment are low social support from family (Foster et al., 2017; Latiff, Rathakrishnan, Jarimal@Safri, Rusdy, \& Lajuma, 2017; Moore \& McArthur, 2014) low social support from peer (Elamouri et al., 2018; Marotta \& Voisin, 2017), low social support from school (Boyas et al., 2017; Foster et al., 2017) and have low family income (Santiago et al., 2017). These shows that low social support from family, peers and school, also low family income lead adolescents to involve in drug risk behaviour. Adolescents who going through this negative or risky environment resulting in low psychological aspect such as resilient and depression are vulnerable towards drug risk behavior (Gattamorta et al., 2016; Hodder et al., 2017; Khalid \& Kausar, 2016; Kurt \& Ergene, 2017).

\section{METHOD}

\section{A. Participants}

Samples of these study were chosen by using cluster random sampling. Every cluster represented by a zone and the 2013 NADA data consist of samples from six different zones in Malaysia which were 
INTERNATIONAL JOURNAL OF ACADEMIC RESEARCH IN BUSINESS AND SOCIAL SCIENCES

Vol. 8, No. 12, Dec, 2018, E-ISSN: $2222-6990$ C 2018 HRMARS

north (Pulau Pinang and Kedah), middle (Selangor and Kuala Lumpur), south (Johor), east (Kelantan), Sabah and Sarawak.

In each zone, each subject was chosen by using purposive random sampling among sample with age of 13 and 14 years' old and they were divided into two group. The first group is the group of adolescents who have the characteristics of not active at school and low academic achievement while the second group characteristics was contradict with the first group characteristics which they were active at school and have high academic achievement. Subject who have either one these two groups characteristics was chosen based on the suggestion from the teachers by following the criteria that have been assigned by the researcher. The inclusion criteria in these study were students from standard 1 and 2 with age 13 and 14 years old and able to understand instruction. While the exclusion criteria of these study was those who refuse to give informed consent.

The original data set consisted of 1357 male and 1537 female subject ( $n=2894$ ). Apart from these characteristics that have been assigned by the researcher, another factor that involve in this study was demographic factor which were gender (male or female), race (Malay, Chinese, Indian, indigenous Sabah or indigenous Sarawak) and location (urban, suburb, rural or Federal Land Development Authority (FELDA)). Details about participant information can be seen in Table 1.

Table 1: Descriptive of Participant Background Information

\begin{tabular}{llcc}
\hline Descriptive Information & & Frequency & Percentage (\%) \\
\hline Gender & Male & 1357 & 46.9 \\
Race & Female & 1537 & 53.1 \\
& Malay & 1716 & 59.3 \\
& Chinese & 610 & 21.1 \\
& Indian & 121 & 4.2 \\
& Indigenous Sabah & 164 & 5.7 \\
& Indigenous Sarawak & 275 & 9.5 \\
& Others & 8 & .3 \\
Parent Marital Status & Married & 2519 & 87.0 \\
& Divorced & 219 & 7.6 \\
Family Income (RM) & Caregiver & 79 & 2.7 \\
& Below 1000 & 930 & 32.1 \\
& 1001 - 3000 & 472 & 16.3 \\
& 3001 - 5000 & 470 & 16.2 \\
& 5001- 7000 & 441 & 15.2 \\
Zone & 7001 and Above & 581 & 20.1 \\
& North & 501 & 17.3 \\
& Middle & 473 & 16.2 \\
& South & 467 & 16.1 \\
& East & 491 & 17.0 \\
& Sarawak & 470 & 16.2 \\
Location & Sabah & 492 & 17.0 \\
& Urban & 861 & 29.8 \\
& Suburban & 414 & 14.3 \\
& Rural & 953 & 32.9 \\
& FELDA & 666 & 23.0 \\
\hline
\end{tabular}




\section{B. Procedure}

In this Pearson correlation analysis, we will analyse data that was obtained from National Anti-Drug Agency about the characteristics of drug risk behavior among adolescents (Mohammad Nasir et al., 2013). In the previous study (Mohammad Nasir et al., 2013), after obtaining approval from the Educational Planning and Research Division in Ministry of Education, State of Education Department, District Education Office and the head of the selected school in the sample, researcher contacted the class teacher and the counsellor which they informed about the nature, purpose and approximate time duration of the data collection. The questionnaire distributed to all subjects by the class teacher and counsellor that was appointed by researcher. A total number of 2894 subject were participated in this study.

\section{Measure}

Instrument that been used in these study was Instrumen Remaja Berisiko Mengambil Dadah (IRBMD) that was develop during these study. This instrument was adapted from the Intsrumen Remaja Berisiko (Mohammad Nasir, 2006) and have 56 items in total with six construct (perception towards family, perception towards friends, perception towards school, resilience, depression and drug risk behavior).

Social support from family, peer and school construct measure how the adolescents perceive their relationship and function of the family, peer and school in their life by using self-report questionnaire of IRBMD. Social support from family measure by using perception towards family construct, social support from peer measure by using perception towards peer construct and social support from school measure by using perception towards school construct. In addition, family income measure by a single item in demographic section that consists multiple choices answer, 1 (below RM 1000), 2 (RM 1000 to RM 3000), 3 (RM 3001 to RM 5000), 4 (RM 5001 to RM 7000) and 5 (RM 7001 and above).

Next, resilience construct measure individual ability in managing various stresses from environmental factors by having a more optimistic future perception, not depend on others and not afraid of taking risk. Moreover, depression construct measure to moodiness like dislike, or the sad feelings experienced by adolescents associated with the protective factor that occur to them such as dealing with non-functioning families, poverty, and other non-supporting social environments such as family, peers and schools. Lastly, drug risk behavior construct is not measure the abusive drug behavior as gazette in the act, but based on an individual theory framework involved in this behavior is risky to engage in drug abuse such as seeing friends taking drug, smoking and sniffing glue.

Details about the positive and negative items in IRBMD can be seen in Table 2. Subjects rate based on five-point Likert scale from 1 (strongly disagree), 2 (disagree), 3 (less disagree), 4 (agree) and 5 (strongly agree) for all constructs except for drug risk behavior construct which are 1 (never), 2 (once), 3 ( 2 to 3 times), 4 (4 to 5 times) and 5 (6 times and more). Total score for each construct calculated by sum up all of the score of the item in each construct and divided by the total number of the item in each construct as shown in Figure 1 below: 
INTERNATIONAL JOURNAL OF ACADEMIC RESEARCH IN BUSINESS AND SOCIAL SCIENCES

Vol. 8, No. 12, Dec, 2018, E-ISSN: 2222-6990 @ 2018 HRMARS

$$
\text { Mean score }=\frac{\text { Total score for each construct }}{\text { Total item for each construct }}
$$

Figure 1: How to calculate total score for each construct in IRBMD

Table 2: List of construct of (IRBMD

\begin{tabular}{lccc}
\hline Construct & Positive Item & Negative Item & Total Item \\
\hline $\begin{array}{l}\text { Perception towards } \\
\text { family } \\
\text { Perception towards } \\
\text { peer }\end{array}$ & $1,2,4,7,9$ and 10 & $3,5,6$ and 8 & 10 \\
$\begin{array}{l}\text { Perception towards } \\
\text { school }\end{array}$ & 16,19 and 20 & 17 and 18 & 5 \\
$\begin{array}{l}\text { Resilience } \\
\text { Depression }\end{array}$ & 13 & $11,12,14$ and 15 & 5 \\
& All items are positive & None & 21 \\
Drug risk behavior & $21,22,23,25,28$, and & 24,26 and 27 & 9 \\
Total & 29 & None & 6 \\
\hline
\end{tabular}

\section{Validity and Reliability of the Instrument}

Table 3 shows the validity and reliability value for the IRBMD which the type validity that have been used in these study was content validity. This category looks at whether the instrument adequately covers all the content that it should with respect to the variable or in other words, does the instrument cover the entire domain related to the variable, or construct it was designed to measure? (Heale \& Twycross, 2015). The validity score based on each construct were varying between .77 to .85 with the total validity score for the instrument was .82 . For reliability score, the Cronbach alpha value for each construct vary between .67 to .92 with total Cronbach alpha value for the instrument was .81. The general rule of thumb suggested ideal Cronbach alpha value is above .70 (good), .80 (better) and .90 (best) (DeVellis, 2003; Rachel, 2018).

Some of the construct have fewer items that is below than 10 items have a quite low Cronbach alpha value as it is quite sensitive to the number of items in the scale (Pallant, 2007). So, Pallant (2007) suggest that it would be more appropriate to report the mean inter-item correlation value for the items. Briggs and Cheek (1986) recommend optimal range for inter-item correlation is between .20 to .40 . The mean inter-item correlation of this instruments vary between .24 to .62 with total average value is .34 that shows an acceptable value. 
INTERNATIONAL JOURNAL OF ACADEMIC RESEARCH IN BUSINESS AND SOCIAL SCIENCES

Vol. 8, No. 12, Dec, 2018, E-ISSN: 2222-6990 @ 2018 HRMARS

Table 3: Validity and reliability of IRBMD

\begin{tabular}{lccc}
\hline Construct & Validity & Reliability & Mean Inter-item Correlation \\
\hline $\begin{array}{l}\text { Perception towards } \\
\text { family }\end{array}$ & .85 & .79 & .29 \\
Perception towards peer & .85 & .63 & .26 \\
Perception towards & .81 & .61 & .24 \\
school & & & \\
Resilience & .83 & .92 & .37 \\
Depression & .77 & .77 & .26 \\
Drug risk behavior & .80 & .90 & .62 \\
Total & .82 & .81 & .34 \\
\hline
\end{tabular}

\section{E. Data Analysis}

Type of analysis that been used in this study is Pearson correlation analysis that was conducted by using Statistical Package for Social Science (21).

\section{RESULTS}

\section{A. Preliminary study}

Data exploratory analysis have been conducted as it is a critical first steps in analyzing the data. This analysis is crucial to detect if there are any outliers and anomalies, maximize insight of the data, test underlying assumption, identifying the most important variables and testing a hypotheses or checking assumptions related to a specific model. The data from previous involve 2894 participants in total consists of secondary school students, standard 1 and standard 2 . This data has been collected to screened the students who will be choose to participate in experiment that have been conducted in the previous study. So, the analysis that have been conducted only descriptive analysis. The data related to variable social support from family, peer and school, family income, depression, resilience and drug risk behavior have been collected. In this study, Pearson correlation analysis will be conducted involving all the variable in the previous study.

In this data exploratory analysis part, we check if there is any error in the data set as it is very easy to make mistakes when entering data and some errors can completely affect the analysis. Some analyses are very sensitive to what are known as outliers, that is, values that are well below or well above the other scores. First, we check if there are any variables scores that out of range which is not within the range of possible score, then, we find where in the data file this error occurred and delete the values.

Table 4 shows the normality of the distribution of score for construct social support from family, social support from peer, social support from school, family income, resilience, depression and drug risk behavior for the sample as a whole. There will be few information that will be highlighted such as the mean, standard deviation, skewness, kurtosis and the normality if the data. As we can see, the mean values range between 1.30 to 4.22 while the standard deviation range from .50 to 1.53 . 
The values for skewness and kurtosis between -2 and +2 are considered acceptable in order to prove normal univariate distribution (George \& Mallery, 2010). For skewness assessment, its showed acceptable value for all variable except for drug risk behavior (3.06) range between -1.26 to .24. The skewness value provides an indication of the symmetry of the distribution. Negative skewness values indicate a clustering of scores at the high end (right-hand side of graph) while positive skewness values indicate positive skew (scores clustered to the left at the low values) (Pallant, 2007).

Next, kurtosis assessment provides information about the peakedness of the distribution. Positive kurtosis values indicate that the distribution is rather peaked (clustered in the centre), with long thin tails, while negative values indicate a distribution that is relatively flat (too many cases in the extremes) (Pallant, 2007). From the analysis, its showed acceptable value for all variable except for resilience (3.5) and drug risk behavior (10.28) range between -1.4 to 1.18.

In the Table 4 labelled Test of Normality, we use values given by Kolmogorov-Smirnov statistics which assesses the normality distribution of scores. A non-significant result was obtained for all variable, .00 that indicates this values violate the assumption of normality (significant value is above .05) and this is quite common in large samples (Pallant, 2007).

Table 4: Descriptive analysis of for all variables in this study

\begin{tabular}{lccccc}
\hline Construct & Mean & $\begin{array}{c}\text { Standard } \\
\text { Deviation }\end{array}$ & Skewness & Kurtosis & $\begin{array}{c}\text { Test of Normality } \\
\text { (Kolmogorov- } \\
\text { Smirnov) }\end{array}$ \\
\hline $\begin{array}{l}\text { Social support from } \\
\text { family }\end{array}$ & 4.22 & .58 & -.91 & .86 & .00 \\
$\begin{array}{l}\text { Social support from } \\
\text { peer }\end{array}$ & 3.62 & .50 & -.71 & 1.18 & .00 \\
$\begin{array}{l}\text { Social support from } \\
\text { school }\end{array}$ & 4.06 & .69 & -.55 & -.13 & .00 \\
$\begin{array}{l}\text { Family income } \\
\text { Resilience }\end{array}$ & 2.75 & 1.53 & .23 & -1.4 & .00 \\
$\begin{array}{l}\text { Depression } \\
\text { Drug risk behavior }\end{array}$ & 4.13 & .57 & -1.26 & 3.50 & .00 \\
& 2.34 & .67 & .24 & -.17 & .00 \\
& 1.30 & .65 & 3.06 & 10.28 & .00 \\
\hline
\end{tabular}

Figure 2 shows the histogram with normal curve on it for variable social support from family, peer and school, family income, resilience, depression and drug risk behavior while Figure 3 shows the boxplot of social support from family, peer and school, family income, resilience, depression and drug risk behavior. 

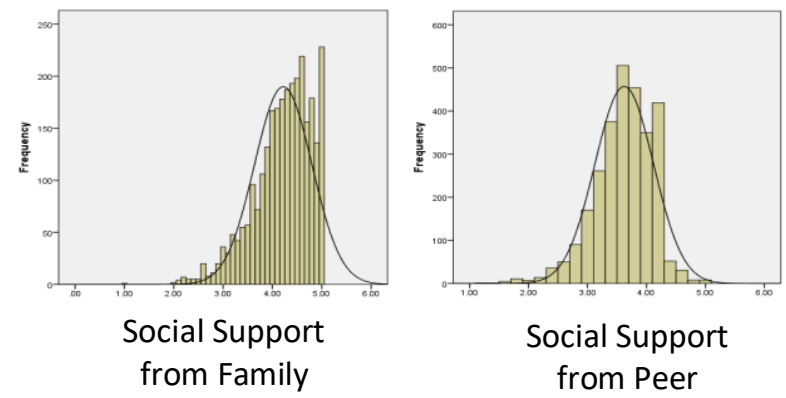

Social Support from Peer
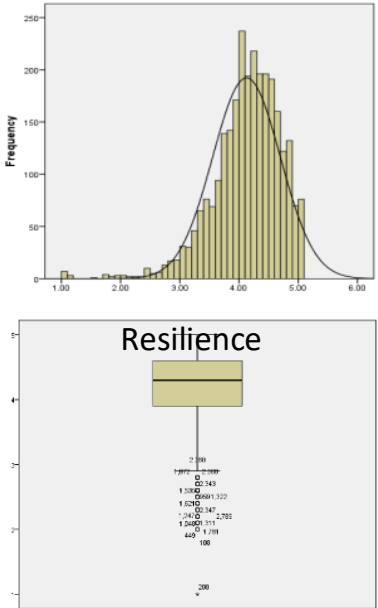

Social Support from Family

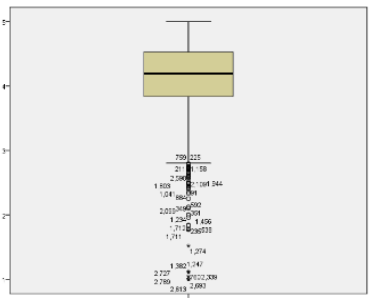

Resilience
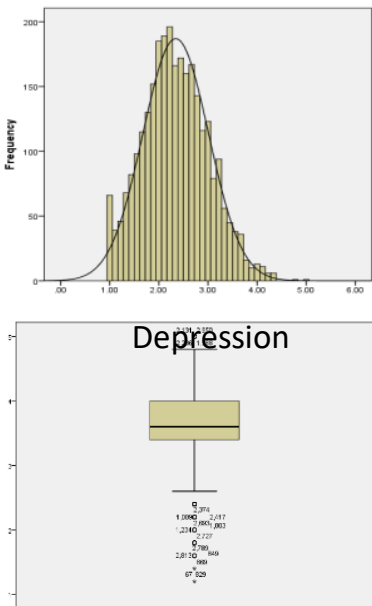

Social Support from Peer

Depression

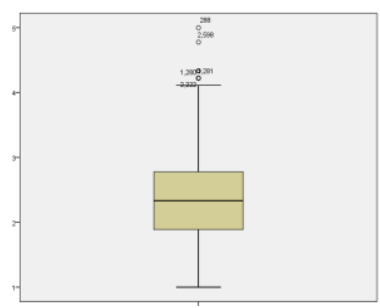

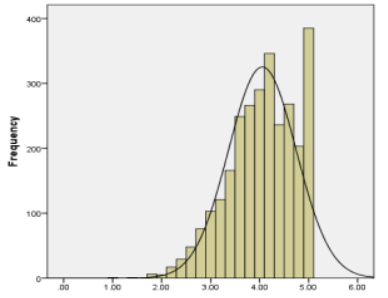

Social Support from School

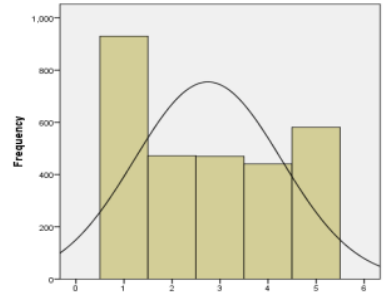

Family Income
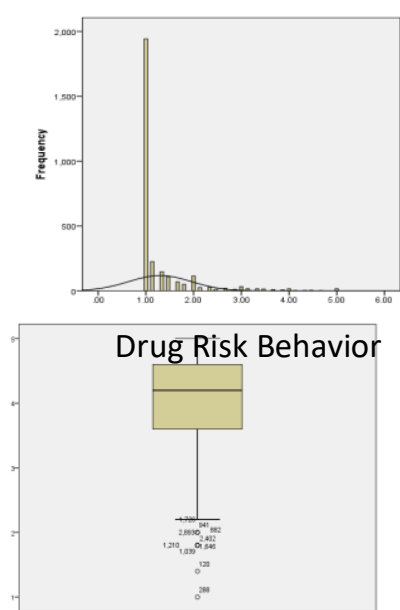

Social Support from School

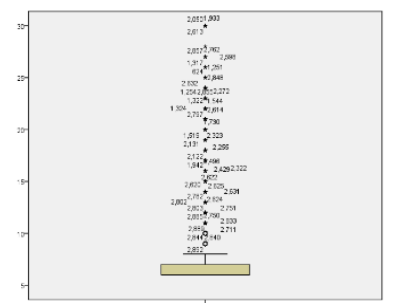

Drug Risk Behavior

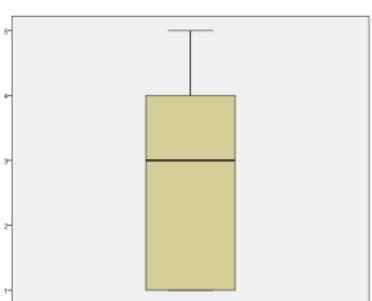

Family Income

Figure 3 Boxplot for variable social support from family, peer, school, family income, resilience,

\section{B. Correlation Analysis depression and drug risk behavior.}

The Pearson's Correlation Table shows that for social support from family construct, it has medium, positive linear relationship with social support from peer $(r=.34)$, social support from school $(r=.49)$ and resilience $(r=.47)$. Also, it has large, negative linear relationship between social support from family and depression $(r=-.53)$, medium with drug risk behavior $(r=-.33)$ and small with family income $(r=-.10)$. Next, social support from peer construct has medium, positive linear relationship with resilience $(r=.41)$ and small, positive linear relationship with social support from school $(r=.27)$. Besides, it has medium, negative linear relationship with depression $(r=-.31)$ and small with drug risk behavior $(r=-.12)$.

Moreover, social support from school has medium, positive linear relationship with resilience $(r=.38)$ and medium, negative linear relationship with depression $(r=-.44)$ and drug risk behavior $(r$ 
INTERNATIONAL JOURNAL OF ACADEMIC RESEARCH IN BUSINESS AND SOCIAL SCIENCES

Vol. 8, No. 12, Dec, 2018, E-ISSN: 2222-6990 @ 2018 HRMARS

$=-.35)$ and small with family income $(r=.10)$. While family income also has negative linear relationship which is medium with drug risk behavior $(r=-.34)$ and small with resilience $(r=-.11)$. Besides, there is medium, negative linear relationship between resilience and depression $(r=-.38)$, drug risk behavior $(r=-.29)$ and there is small, positive linear relationship between depression and drug risk behavior $(r=.29)$.

Table 5: Correlation between construct IRBMD

\begin{tabular}{|c|c|c|c|c|c|c|c|c|}
\hline No. & Variables & 1 & 2 & 3 & 4 & 5 & 6 & 7 \\
\hline \multirow[t]{2}{*}{1} & Social Support from Family & 1.00 & $.34^{* *}$ & $.49 * *$ & - & $.47^{* *}$ & 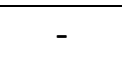 & - \\
\hline & & & & & $.10^{* *}$ & & $.53^{* *}$ & $.33^{* *}$ \\
\hline \multirow[t]{2}{*}{2} & Social Support from Peer & & 1.00 & $.27^{* *}$ & -.02 & $.41 * *$ & - & - \\
\hline & & & & & & & $.31^{* *}$ & $.12^{* *}$ \\
\hline \multirow[t]{2}{*}{3} & Social Support from School & & & 1.00 & - & $.38^{* *}$ & 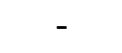 & - \\
\hline & & & & & $.10^{* *}$ & & $.44 * *$ & $.35 * *$ \\
\hline \multirow[t]{2}{*}{4} & Family Income & & & & 1.00 & - & .03 & - \\
\hline & & & & & & $.11 * *$ & & $.34 * *$ \\
\hline \multirow[t]{2}{*}{5} & Resilience & & & & & 1.00 & - & - \\
\hline & & & & & & & $.38 * *$ & $.34^{* *}$ \\
\hline 6 & Depression & & & & & & 1.00 & $.29 * *$ \\
\hline 7 & Drug Risk Behavior & & & & & & & 1.00 \\
\hline
\end{tabular}

\section{DISCUSSION, CONCLUSION AND SUGGESTION}

The purpose of this paper is to conduct Pearson correlation analysis to see the relationship or association between variable in this data set that was obtain from the previous research conducted by Mohammad Nasir et al. (2013) which their aim of study is to acquire a descriptive information about the adolescent of involve in drug risk behaviour.

From the Pearson correlation analysis that have been conducted, results revealed that there is significant positive linear relationship between drug risk behavior and depression which means that when high level of depression associated with high level of drug risk behavior. This finding is parallel with the study conducted by (Jackson, Seth, DiClemente \& Lin, 2015; Khalid \& Kausar, 2016; Halpern \& Herring, 2016; Seil, Desai \& Smith, 2014; Schuler et al., 2015; Trorikka, 2017) but contradict with (Kurt \& Ergene, 2017).

Moreover, there is also negative linear relationship between drug risk behavior and social support from family, peer and school, family income and resilience which means high level of drug risk behavior associated with low level of social support from family, peer and school, family income and resilience and paralled with founding from study by (Grigsby, Forster, Soto, BaezcondeGarbanati, \& Unger, 2014; Hodder et al., 2016; Khalid \& Kausar, 2016; Kurt \& Ergene, 2017; Sanders, Munford, Thimasarn-anwar, Liebenberg, \& Ungar, 2015). 
Based on the results of this study, this study recommended the future research to conduct a longitudinal study to clarify the association between social support from family, peer and school, family income, resilience, depression and drug risk behavior or use another statistical method such as regression or structural equation modelling (SEM). Through that analysis, we can have a solid model that predict the drug risk behavior among Malaysian adolescent. Besides, future studies may investigate the association or effect of another environmental and personal variable that can predict drug risk behavior such as coping skills, aggression, neighbourhood or academic achievement.

\section{ACKNOWLEDGEMENT}

The data in this research was obtained from the study conducted by Mohammadd Nasir et al. (2013) where their study was supported by grants from the Malaysia National Anti-Drug Abuse.

\section{CORRESPONDING AUTHOR}

Nor Hafifah Abdullah

Email: fyfah1701@gmail.com

\section{REFERENCES}

Agensi Anti Dadah Kebangsaan (2017). Jumlah penagih dadah mengikut umur ketika dikesan 20102016. Retrieved from http://www.data.gov.my/data/ms_MY/dataset/jumlah-penagihmengikut-umur-ketika-dikesan/resource/c9172c21-2cf3-46b5-aec9-6ee0e6a28915

Alexander, A. C., Obong'o, C. O., Chavan, P., Vander Weg, M. W., \& Ward, K. D. (2017). Applying the Problem Behavior Theory to Adolescent Drug Use Among a Cross-Sectional Sample of Boys Participating in a Community-Based Youth Organization. Substance Use and Misuse, 53(4), 610621. https://doi.org/10.1080/10826084.2017.1349802

Anderson, D. M., Cesur, R., \& Tekin, E. (2015). Youth depression and future criminal behavior. Economic Inquiry, 53(1), 294-317. https://doi.org/10.1111/ecin.12145

Baharudin, R., Krauss, S. E., Yacoob, S. N., \& Pei, T. J. (2017). Family processes as predictors of antisocial behaviors among adolescents from urban, single-mother Malay families in Malaysia. Journal of Comparative Family Studies, 42(4), 509-522.

Boyas, J. F., Kim, Y. J., Moon, S. S., Ruiz, E., \& Gaines, K. (2017). Drug and alcohol use and its relationship to self-rated health: An ecological examination among Latino and non-Hispanic White adolescents. Children and Youth Services Review, 73, 454-466. https://doi.org/10.1016/j.childyouth.2016.11.020

Briggs, S.R., \& Cheek, J.M. (1986). The role of factor analysis in the development and evaluation of personality scales. Journal of Personality, 54, 106-48.

Camfield, L., \& Palmer-Jones, R. (2013). Improving the quality of development research: What could archiving qualitative data for reanalysis and revisiting research sites contribute? SAGE Journals, 13(4),323-328

Clapp, T. L., Isom, K. A., \& Thomas, A. L. (2016). Substance use in college students predicting substance use in female college students from the coping self-efficacy scale, the resilience scale, and the perceptions of parenting scale. Paper presented to the Faculty of the Department of Psychology, Brenau University, United State. 
INTERNATIONAL JOURNAL OF ACADEMIC RESEARCH IN BUSINESS AND SOCIAL SCIENCES

Vol. 8, No. 12, Dec, 2018, E-ISSN: 2222-6990 @ 2018 HRMARS

Cox, R. B., Criss, M. M., Harrist, A. W., \& Zapata-Roblyer, M. (2017). Are Negative Peer Influences Domain Specific? Examining the influence of peers and parents on externalizing and drug use behaviors. Journal of Primary Prevention, 38(5), 515-536. https://doi.org/10.1007/s10935017-0488-1

DeVellis, R. E. (2003). Scale development: Theory and applications (2nd edn). Thousand Oaks, California: Sage.

Elamouri, F. M., Musumari, P. M., Techasrivichien, T., Farjallah, A., Elfandi, S., Alsharif, O. F., ... Kihara, M. (2018). "Now drugs in Libya are much cheaper than food": A qualitative study on substance use among young Libyans in post-revolution Tripoli, Libya. International Journal of Drug Policy, 53, 23-31. https://doi.org/10.1016/j.drugpo.2017.11.026

Foster, C. E., Horwitz, A., Thomas, A., Opperman, K., Gipson, P., Burnside, A., ... King, C. A. (2017). Connectedness to family, school, peers, and community in socially vulnerable adolescents. Children and Youth Services Review, 81(February), 321-331. https://doi.org/10.1016/j.childyouth.2017.08.011

Gattamorta, K. A., Varela, A., McCabe, B. E., Mena, M. P., \& Santisteban, D. A. (2016). Psychiatric symptoms, parental attachment, and reasons for use as correlates of heavy substance use among treatment-seeking Hispanic adolescents. Substance Use and Misuse, 52(3), 392-400. https://doi.org/10.1080/10826084.2016.1229338

Heale, R., \& Twycross, A. (2015). Validity and reliability in quantitative studies. Evidence Based Nursing, 18(3), 66-67. http://dx.doi.org/10.1136/eb-2015-102129

Hodder, R. K., Freund, M., Bowman, J., Wolfenden, L., Gillham, K., Dray, J., \& Wiggers, J. (2016). Association between adolescent tobacco, alcohol and illicit drug use and individual and environmental resilience protective factors. BMJ Open, 6(11). https://doi.org/10.1136/bmjopen-2016-012688

Hussain, S. Z. (2012). Annual Report "Drug Addiction - Facts about Lahore 2012". Youth Council for Anti-Narcotics (YOCFAN).

Jessor, R., \& Jessor, S. (1977). Problem behavior and psychosocial development: A longitudinal study of youth. New York, NY, USA: Academic Press.

Jordan, C. J., \& Andersen, S. L. (2017). Sensitive periods of substance abuse: Early risk for the transition to dependence. Developmental Cognitive Neuroscience, (25), 29-44. https://doi.org/10.1016/j.dcn.2016.10.004

Khalid, S., \& Kausar, R. (2016). Protective factors, drug use and depression in young drug users. Journal of Behavioural Sciences, 26(2), 1-21.

Kurt, D. G., \& Ergene, T. (2017). Prediction of risk behaviours among Turkish adolescents. Education and Science, 42(189), 137-152. https://doi.org/10.15390/EB.2017.6354

Latiff, A. C., Rathakrishnan, B., Jarimal@Safri, N., Rusdy, S. N. F. S., \& Lajuma, S. (2017). Perkaitan antara perapatan ibubapa dan rakan sebaya dengan penglibatan remaja. Southeast Asia Psychology Journal, 5, 12-21.

Lawrence-Lo. (2009). Familial and socioeconomic influences on substance abuse: an ecological model. Undergraduate Journal of Psychology, 2, 5-10. 
INTERNATIONAL JOURNAL OF ACADEMIC RESEARCH IN BUSINESS AND SOCIAL SCIENCES

Vol. 8, No. 12, Dec, 2018, E-ISSN: 2222-6990 @ 2018 HRMARS

Marotta, P. L., \& Voisin, D. R. (2017). Testing three pathways to substance use and delinquency among low-income African American adolescents. Children and Youth Services Review, 75, 7-14. https://doi.org/10.1016/j.childyouth.2017.02.009

Measure Evaluation (2018, May 24). Secondary data analysis. Retrieved from https://www.measureevaluation.org/our-work/secondary-data-analysis

Mohd Hilmie, H. (2018, February 15). AADK kesan 2,100 murid, pelajar terbabit dadah. Berita Harian. Retrieved from https://www.bharian.com.my/berita/kes/2018/02/389019/aadk-kesan-2100murid-pelajar-terbabit-dadah

Mohd Nasir, B. (2006), Kesan kaunseling kelompok terhadap penyesuaian remaja berisiko. Universiti Kebangsaan Malaysia: Malaysia.

Mohd Nasir, B. et al. (2013), Remaja berisiko mengambil dadah: Langkah pengesanan dan pencegahan awal. Laporan penyelidikan gran Agensi Antidadah Kebangsaan yang tidak diterbitkan, Universti Pendidikan Sultan Idris: Malaysia.

Mohd Nasir, B., \& Jusoh, A. J. (2013). Kesan kaunseling kelompok penyesuaian remaja terhadap kemurungan dan resilien dalam kalangan remaja berisiko mengambil dadah. Journal of Chemical Information and Modeling, 53(9), 1689-1699. https://doi.org/10.1017/CBO9781107415324.004

Mohd Razali, M. M. S. (2015). Implikasi kajian risiko dan pelindung penyalahgunaan dadah dalam kalangan remaja dan belia terhadap program pencegahan dadah. Journal Antidadah Malaysia, (1), 6. Retrieved from http://www.adk.gov.my/html/pdf/jurnal/2015/IMPLIKASI KAJIAN RISIKO DAN PELINDUNG PENYALAHGUNAAN DADA.pdf

Moore, T., \& McArthur, M. (2014). If only I, they, we had done things differently: Young people talk about school difficulties and crime. Children and Youth Services Review, 44, 249-255. https://doi.org/10.1016/j.childyouth.2014.06.015

Nachiappan, S. (2015b). Analisis faktor penyumbang terhadap penyalahgunaan dadah dan usaha pemulihan dari segi kognisi di Pusat Pengasih Malaysia. Educatum-Journal of Social Science, 1, 34-39.

Newsome, J., \& Sullivan, C. J. (2014). Resilience and vulnerability in adolescents: Genetic influences on differential response to risk for delinquency. Journal of Youth and Adolescence, 43(7), 10801095. https://doi.org/10.1007/s10964-014-0108-9

Omboto, J. O., Ondiek, G. O., Odera, O., \& Ayugi, M. E. (2013). Factors influencing youth crime and juvenile delinquency. International Journal of Research in Social Sciences, 1(2), 18-21.

Palamar, J. J., Griffin-Tomas, M., \& Ompad, D. C. (2015). Illicit drug use among rave attendees in a nationally representative sample of US high school seniors. Drug and Alcohol Dependence, 152, 24-31

Pallant, J. (2007). SPSS survival manual a step by step guide to data analysis using SPSS for Windows third edition. London: The McGraw-Hill Companies.

Pandian, R. D., \& Lakshmana, G. (2017). Risk and resilience factors for substance use among street adolescents: Assessment and development of an integrative model. Asian Social Work and Policy Review, 11(3), 216-233. https://doi.org/10.1111/aswp.12127

Racal, S. J. (2017). Resilience and substance abuse among school-aged children. St. Theresa Journal of Humanities and Social Sciences, 3(1), 48-57. 
Roche, D. G., Lanfear, R., Binning, S. A., Haff, T. M., Schwanz, L. E., Cain, K. E., Kokko, H., Jennions, M. D., Kruuk, L. E. B. (2014). Troubleshooting public data archiving: Suggestions to increase participation. PLOS Biology 12 (art. e1001779).

Rovis, D., Bezinovic, P., \& Basic, J. (2015). Interactions of school bonding, disturbed family relationships, and risk behaviors among adolescents. Journal of School Health, 85(10), 671-679. https://doi.org/10.1111/josh.12296

Santiago, A. M., Lee, E. L., Lucero, J. L., Foundation, K., Develop-, U., Berg, K., ... Lansing, E. (2017). How living in the 'hood affects risky behaviors among Latino and African American youth. RSF: The Russell Sage Foundation Journal of the Social Sciences, 3(2), 170-209. https://doi.org/10.7758/RSF.2017.3.2.08.

Sharif, Z., \& Mohammad Roslan, N. (2011). Faktor-faktor yang mempengaruhi remaja terlibat dalam sosial, masalah sekolah, di Tunas Bakti, Sungai Lereh. Journal of Education Psychology \& Counseling, 1, 115-140.

Skogen, J. C., Sivertsen, B., Lundervold, A. J., Stormark, K. M., Jakobsen, R., \& Hysing, M. (2014). Alcohol and drug use among adolescents: And the co-occurrence of mental health problems. Ung@hordaland, a population-based study.BMJ Open, 4(9). https://doi.org/10.1136/bmjopen2014-005357

Taylor, S. D., \& Distelberg, B. (2016). predicting behavioral health outcomes among low-income families: Testing a socioecological model of family resilience determinants. Journal of Child and Family Studies, 25(9), 2797-2807. https://doi.org/10.1007/s10826-016-0440-7

Torikka, A. (2017). Depression and substance use in middle adolescence. Acta Electronica Universitatis Tamperensis. Retrieved from http://tampub.uta.fi/bitstream/handle/10024/101793/978-95203-0470 6.pdf?sequence $=1$

Turnbridge. (2018, June 5). Adolescent drug use: Do new numbers bode well for 2018? Retrieved from https://www.tpaddictiontreatment.com/news-events/adolescent-drug-use

Vartanian, T. P. (2011). Secondary data analysis. New York: Oxford University Press.

Wang, H. (2014). The relationship between parenting styles and academic and behavioral adjustment among urban Chinese Adolescents. Chinese Sociological Review, 46(4), 19-40. https://doi.org/10.2753/CSA2162-0555460402

World Health Organization (2009). Health of adolescents in Malaysia. Retrieved from http://www.wpro.who.int/topics/adolescent_health/malaysia_fs.pdf

World Health Organization (2017). Adolescent health. Retrieved from http://www.who.int/topics/adolescent_health/en/ 